\title{
Die funksie van die 'danksegging(s)' in 1 Tessalonisense
}

\author{
E Cornelius \\ Potchefstroomse Universiteit vir CHO
}

\begin{abstract}
The function of the 'thanksgiving(s)' in 1 Thessalonians

The aim of this article is to determine the possible communicative function(s) of the 'thanksgiving(s)' in 1 Thessalonians. Traditionally more than one 'thanksgiving' is identified in this letter (contrasting the other Pauline letters containing only one 'thanksgiving'). Approaches like the formalist and/or 'content' approaches are rendered as inadequate to deal with this problem. The interactive model seems to be a more satisfactory approach to determine the function(s) of these sections in 1 Thessalonians. This approach leads to the conclusion that 'thanksgiving' is a misnomer for these sections in 1 Thessalonians; their function is rather to render the implied reader favourable towards the encoded author so that he/she can be receptive to his argumentation.
\end{abstract}

\section{INLEIDING}

Die oogmerk met hierdie artikel is om die kommunikatiewe funksie(s) van die gedeeltes in 1 Tessalonisense wat tradisioneel as 'danksegging(s)' bestempel word, te beskryf.

Schubert (1939) en O'Brien (1977) het baie gedoen om die 'dankseggingstrukture' en die funksie(s) daarvan te beskryf. O'Brien (1977:141-142) identifiseer die vol-

- Hicrdic artikel is 'n uittreksel uit 'n MA-verhandeling in Grieks aan die PU vir CHO in 1991, met dr. Jan Botha as studicleier. 
gende drie 'dankseggingsgedeeltes' in 1 Tessalonisense op grond van die twee tipes 'dankseggingstrukture' wat Schubert (1939:10-39) onderskei: 1 Tessalonisense 1:210, 2:13-16 en 3:9-13. Schubert (1939:21), aan die ander kant, beskou hierdie drie betrokke gedeeltes as een lang 'danksegging'.

Hieruit is dit duidelik dat daar verskillende menings oor die afbakening van die 'danksegging(s)' in 1 Tessalonisense bestaan. As gevolg van die probleem om die 'danksegging(s)' in 1 Tessalonisense af te baken, is daar in die navorsingstradisie verskillende teorieë op die tafel geplaas betreffende die ontstaan en struktuur van 1 Tessalonisense.

Omdat antieke briewe, en in besonder die ander Pauliniese briewe, gewoonlik slegs een 'danksegging' bevat en dan wel in die briefopening (vgl die 'dankseggingsgedeeltes' in Rom 1:8-12; Kol 1:3-14; Fil 1:3-11; Filem 4-6; 1 Kor 1:3-11), skep die drie 'dankseggingsgedeeltes' in 1 Tessalonisense vir talle Nuwe-Testamentici 'n probleem. In die hantering van die integriteit en eenheid van 1 Tessalonisense en in die besonder van 1 Tessalonisense 2:13-16, gee Schmidt (1983:269-279), Pearson (1971:79-94), Best (1972:29-34) en Collins (1979:67-106) 'n kort samevatting van die ontwikkeling van interpolasie - en konflasieteorieë in verband met hierdie probleem.

Die voorkoms van meerdere 'dankseggings' in 1 Tessalonisense het sommige Nuwe-Testamentici daartoe gebring om 1 Tessalonisense of as 'n samestelling van meerdere briewe te beskou of die meerdere 'dankseggings' te verklaar as 'n gevolg van redaksionele werk of as 'n gevolg van interpolasie.

Wanneer kommentare (vgl o a Meyer 1880; Finday 1914; Van Leeuwen 1926; Frame 1946; Morris 1959, 1960; Grayston 1967; Sparks 1969; Hiebert 1974; Bolkestein 1974; Kümmel 1975) oor 1 Tessalonisense geraadpleeg word, word dit duidelik dat die meerdere 'dankseggings' in 1 Tessalonisense ook vir kommentatore 'n probleem skep. Veral die tweede en derde 'dankseggingsgedeeltes' in 1 Tessalonisense (2:13-16; 3:9-13) word nie op grond van formeel-literêre en grammatikale oorwegings deur baie kommentatore as briefdeel geidentifiseer en afgebaken nie, maar wel op grond van die saak of inhoud wat in die betrokke gedeeltes aan die orde kom.

Uit die navorsingstradisie blyk dit dat hierdie Nuwe-Testamentici veral saaklik en/of deskriptief-formalisties te werk gaan in hulle afbakening van 1 Tessalonisense. Nie een van hierdie voorstelle bied myns insiens 'n bevredigende verduideliking vir die afbakening en beskrywing van die funksie(s) van die 'danksegging(s)' in 1 Tessalonisense nie. Daar sal ook moeilik vordering gemaak word indien daar slegs met saaklike en formalistiese oorwegings rekening gehou word. 
Dit is ' $n$ algemene tendens in die studie van die Nuwe-Testamentiese briewe dat hulle beskou word as bronne wat inligting oordra oor werklike historiese situasies. Vorster (1991:39) kritiseer hierdie benadering in sy studie van die Romeinebrief. Ook ten opsigte van die studie van 1 Tessalonisense kan hierdie algemene tendens waargeneem word. Hierdie aanname oor die aard van die Nuwe-Testamentiese briewe bring mee dat baie van hierdie studies nie genoegsaam aandag skenk aan die kommunikatiewe funksie van 'n brief nie (kyk Violi 1985:160). Die inligting wat 'n brief oordra, kan nie bepaal word sonder om die implikasie van die feit dat briewe 'n interaksie verteenwoordig, in ag te neem nie (kyk Vorster 1990:107-130).

Om die kommunikatiewe funksie van 'n linguale element te bepaal, verg 'n retoriese en pragmatiese benadering, aangesien beide hierdie dissiplines die retoriese konteks of situasie (d w s die konteks van interaksie) in aanmerking neem. Retoriek en pragmatiek het dus albei 'n plek binne die sfeer van interaksie (Vorster 1991: 21).

Omdat daar egter 'n noue verband tussen retoriek en epistolografie bestaan, is dit noodsaaklik om ook epistolografies te werk te gaan. In die navorsingstradisie is daar uiteenlopende standpunte oor hoe die verhouding tussen retoriek en epistolografie beskou moet word. In moderne studies word hierdie probleem rondom die verhouding lukraak hanteer. In talle analises lyk dit asof die begin en einde van briewe epistolografies bestudeer word, terwyl die briefliggaam retories bestudeer word (vgl Snyman 1989). By die interpretasie van briewe is 'n kombinasie van beide retoriek en epistolografie die ideaal, veral wanneer dit die ideaal is om nie slegs formalisties te werk te gaan nie, maar ook kommunikatief-funksioneel. Daarom word epistolografie in hierdie artikel ingespan om die 'danksegging(s)' in 1 Tessalonisense formeel te ontleed, waarna retoriek ingespan word om die kommunikatiewe funksies te bepaal.

Teen hierdie agtergrond word die volgende prosedure gevolg ten einde die funksie(s) van die 'danksegging(s)' in 1 Tessalonisense te beskryf:

- 'n Analise van die epistolêre vorm van 1 Tessalonisense;

* 'n Analise van die gespreksituasie aan die hand van deiktiese elemente in die 'danksegging(s)' (dus 'n pragmatiese analise);

* 'n Toepassing van die koöperatiewe beginsel op hierdie deiktiese elemente ('n pragmatiese benadering);

- 'n Bepaling van die funksie(s) van die 'danksegging(s)' in 1 Tessalonisense op grond van ' $n$ analise van die retoriese situasie;

- 'n Algemeen retoriese indeling van die brief op grond van die funksie(s) en tónot van die verskillende retoriese dele. 
2. DIE EPISTOLARE VORM VAN 1 TESSALONISENSE AS GEHEEL

Volgens Deissmann (1901:168), Doty (1973:27) en White (1984:1739-1749) bestaan die Pauliniese brief kenmerkend uit die volgende dele:

* briefopening ('prescript'),

* danksegging,

* briefliggaam,

- apostoliese parousia,

* vermaning ('exhortation'),

* briefslot.

Vervolgens word hierdie verskillende briefdele in 1 Tessalonisense geïdentifiseer en bespreek.

\subsection{Die briefopening}

Terwyl Deissman (1901:168), Doty (1973:27) en White (1984:1739-1749) die 'briefopening' van die 'danksegging' skei, noem Boers (1975/1976:140) dat dit belangrik is om 'n onderskeid te tref tussen die 'danksegging' en die 'openingsgroet'. Hierdie twee gedeeltes funksioneer saam as die 'briefopening'.

\subsubsection{Die openingsgroet}

Die openingsgroet van 1 Tessalonisense kom voor in 1:1 (kyk Johanson 1987:60):

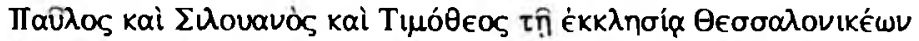

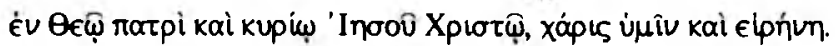

(Paulus en Silas en Timoteus aan die gemeente van die Tessalonisense wat in God die Vader en die Here Jesus Christus is, genade vir julle en vrede.)

Die briefopening van 1 Tessalonisense volg die normale patroon van die openingsgroet, gebaseer op die Hellenistiese vorm: A aan B $\chi \alpha$ ípewv. Onder die invloed van

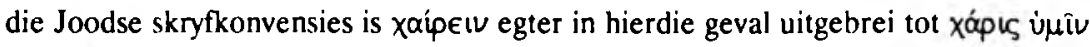
kaì Eiprin (kyk Doty 1973:22).

Dit is noodsaaklik om hier 'n onderskeid te tref tussen die werklike skrywer (historiese skrywer) en die skrywer wat in die teks teenwoordig is (die geënkodeerde outeur). Die historiese en empiriese skrywer van 'n brief kan, vanweë die tekstuele aard van 'n brief, nie sonder meer op 'n simplistiese wyse gelyk gestel word aan dit wat as die skrywer in die teks aanwesig is nie. Gevolghik word daar in hier- 
die artikel verwys na die geënkodeerde outeur van 1 Tessalonisense. Op dieselfde wyse moet daar ook onderskei word tussen die werklike en implisiete leser.

Op grond van die briefsituasie word die gegewens oor die geënkodeerde outeur

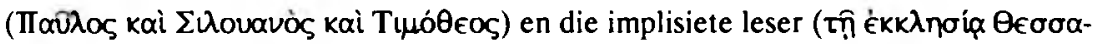
$\lambda o \nu$ Iké $\omega v)$ in die openingsgroet van 1 Tessalonisense verder uitgebrei.

\subsubsection{Die geënkodeerde outeur}

Alhoewel drie persone, naamlik Paulus, Silas en Timoteus, genoem word as die skrywers of afsenders van hierdie brief, is die begrip 'geënkodeerde outeur' 'n enkelvoudsbegrip wat op 'n tekstuele abstraksie dui. In hierdie studie word dus deurgaans in die enkelvoud van die 'geënkodeerde outeur' gepraat, selfs al word die skrywers of afsenders van die brief as drie persone geidentifiseer.

In die openingsgroet word daar betreklik min inligting oor die geënkodeerde outeur verstrek. Dit op sigself kan alreeds iets sê van die verhouding tussen die geënkodeerde outeur en die implisiete leser. In hierdie geval veronderstel die geënkodeerde outeur kennis oor homself by die leser en ag dit daarom nie nodig om hom verder bekend te stel nie. Die res van die brief aan die Tessalonisense bevestig hierdie stelling oor die twee partye se bekendheid met mekaar. Deur die loop van

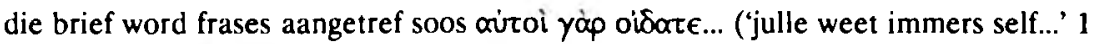

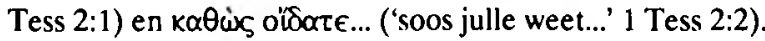

\subsubsection{Die implisiete leser}

Alhoewel daar na die lesers van hierdie brief slegs in die meervoudsvorm verwys word, naamlik 'die Tessalonisense', word in hierdie studie van die 'implisiete leser' (enkv) gepraat, wat op 'n tekstuele abstraksie dui.

Dit is insiggewend om 'n vergelyking te tref tussen die implisiete leser van 1 Tessalonisense en dié in die twee papiri PCol HI 6 en PHibeh I 43. In die openingsgroet van PCol III 6 (teks uit White 1986:33) skryf Simale aan Zenon: $\Sigma \psi u a ́ \lambda_{\eta}$

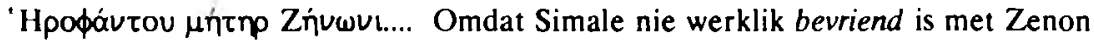
nie, is dit vir haar nodig om haarself te identifiseer in terme van 'n persoon wat wel met Zenon bevriend is, naamlik haar seun. In PHibeh 143 (teks uit White 1986:25)

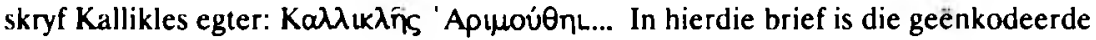
outeur skynbaar bevriend met die implisiete leser en is dit daarom nie nodig dat Kallikles homself verder identifiseer nie.

Soos in die geval van die geënkodeerde outeur, word ook die implisiete leser in die openingsgroet van 1 Tessalonisense slegs genoem. Daar word in hierdie stadium 
geen verdere inligting oor die implisiete leser verskaf nie. In terme van antieke briefkonvensies dui dit daarop dat daar wel gedeelde kennis tussen die twee partye bestaan en dat die twee partye reeds vóor die skryf van die brief aan mekaar bekend was (vgl Petersen 1985:49).

\subsubsection{Die 'danksegging(s)'}

Die 'danksegging(s)' (geïdentifiseer in terme van die struktuurelemente wat Schubert [1939] voorstel) kom in drie gevalle in 1 Tessalonisense voor, naamlik in 1:2-10, 2:13-16 en 3:9-13.

(a) 1 Tessalonisense 1:2-10

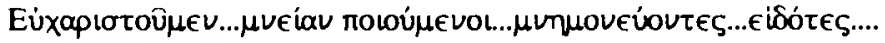

(b) 1 Tessalonisense 2:13-16

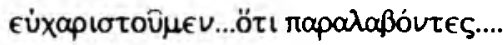

(c) 1 Tessalonisense 3:9-13

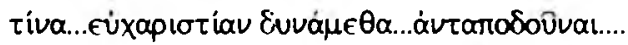

Vorster (1990:115) verstrek 'n aantal reëls vir 'n taaluiting van danksegging, gebasseer op die teorie van Searle (1971:52): In die geval van 'n brief

- verrig die leser 'n daad tot voordeel van 'n ander party (wat moontlik die outeur self is);

* het die outeur 'n positiewe gesindheid teenoor die leser (in die geval van 'n danksegging - die party wat bevoordeel en gevolglik die dank ontvang);

* beskou die outeur die daad, verrig deur die leser, as voordelig vir die bevoordeelde party;

- beskou die outeur die leser as die oorsaak van die goeie daad;

* word die leser vir sy goeie daad bedank.

Wanneer die 'danksegging(s)' in 1 Tessalonisense ontleed word, word dit duidelik dat dit nie aan hierdie reëls vir 'n danksegging voldoen nie. Alhoewel die drie 'dankseggingsgedeeltes' 'n taalhandeling is waarin die geënkodeerde outeur sy dank uitspreek, kan die betrokke gedeeltes om die volgende redes nie as dankseggings getipeer word nie: 
* 'n Derde party, naamlik God (ó Өєós), verrig 'n goeie daad teenoor die implisiete leser (1 Tess $1: 2 ; 2: 13 ; 3: 9$ ).

* Die geënkodeerde outeur het 'n positiewe gesindheid teenoor 'n party, anders as die party wat die dank ontvang, naamlik die implisiete leser, soos dit byvoorbeeld blyk uit die stelling in 1 Tessalonisense 3:9.

* Die geënkodeerde outeur beskou die daad, verrig deur die derde party, as voordelig vir die implisiete leser (vandaar die blydskap oor die implisiete leser in 1 Tess $1: 2 ; 2: 13 ; 3: 9)$.

* Die geënkodeerde outeur beskou die derde party as die oorsaak van die goeie daad (kyk die datiewe in 1 Tess $1: 2 ; 2: 13 ; 3: 9$ ).

* Die derde party word bedank vir die goeie daad (kyk na die werkwoordvorm

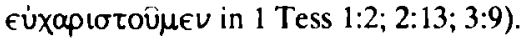

In hierdie drie 'dankseggingsgedeeltes' word die derde party dus bedank en nie die implisiete leser nie. In die lig van die taalhandeling soos wat dit ontleed is, blyk dit dus dat 'danksegging' miskien nie die gewenste benaming vir hierdie gedeeltes in 1 Tessalonisense is nie. Vorster (1990:115) stel voor dat hierdie gedeeltes eerder beskou moet word as politeness strategies. 1 Tessalonisense is nie ' $n$ brief aan die Tessalonisense met die doel om hulle te bedank vir iets nie. Aangesien hierdie drie gedeeltes in 1 Tessalonisense (1:2;2:13; 3:9) moeilik as danksegging(s) getipeer kan word, is dit belangrik om te bepaal wat die kommunikatiewe funksie van hierdie gedeeltes dan wel is. Aangesien die doel van hierdie artikel juis is om die funksie van die 'danksegging' te bepaal, word die term 'danksegging' steeds gebruik, maar wel in aanhalingstekens, totdat hierdie gedeeltes in die konklusie anders getipeer word.

\subsection{Dic briefliggaam}

White (1972:1-42) bespreek die briefliggaam van antieke Griekse briewe in detail aan die hand van tipiese frases en formules. In dieselfde werk (1972:43) bespreek hy die struktuur van die Pauliniese briefliggaam oor die algemeen en daarna die briefliggaam van 1 Tessalonisense in besonder (White 1972:68).

White (1972:71) baken die onderafdelings van die briefliggaam van 1 Tessalonisense soos volg af:

* briefliggaam-opening: 2:1-4;

* briefliggaam-middel: 2:5-16;

* briefliggaam-slot: 2:17-3:10.

Schubert (1939:16-27) tipeer 1 Tessalonisense 1:2-3:13 (die drie 'dankseggingsgedeeltes' is dus ingesluit) as die liggaam van die brief, omdat die drie 'dankseggings- 
gedeeltes' (vanaf 1:2 tot 3:16) volgens hom 'n eenheid vorm. Daarom sê hy dat die danksegging in 1 Tessalonisense nie, soos in die geval van ander Pauliniese briewe, slegs inleidend tot die briefliggaam is nie, maar dat hierdie danksegging self die briefliggaam vorm (Schubert 1939:26).

White (1972:70) bevestig die standpunt van Schubert in 'n mate. Hy meen dat Schubert tereg aan die danksegging(s) in 1 Tessalonisense 'n belangrike epistolêre funksie (die funksie van die briefdeel binne die brief as geheel) toeken. Tog beskou White die danksegging(s) nie as die briefliggaam nie. Dit is egter insiggewend dat hy in sy afbakening van die briefliggaam wel die gedeelte vanaf $2: 1$ onder die briefliggaam insluit. Dit lyk dus of White hierdie teenstrydigheid oorkom wanneer hy beweer dat die briefliggaam op die danksegging(s) steun.

White maak die bovermelde analise van 1 Tessalonisense op grond van oorgangsfrases. Hierdie oorgangsfrases beskou hy as konvensionele frases wat oorgange vanaf die een briefdeel na 'n ander vorm, of van een onderwerp na 'n ander (White 1972:1-2). Sommige van hierdie frases is kenmerkend te vind in slegs een briefdeel, terwyl ander frases in al die briefdele kan voorkom. In sy ontleding van antieke briewe verstrek White (1972:2-37) voorbeelde van al hierdie tipiese oorgangsfrases.

Die enigste werklike oorgangsfrase na die briefliggaam in 1 Tessalonisense op grond waarvan hy die briefliggaam-opening afbaken, is die volgende: Aúcol $\gamma \alpha \dot{\alpha} \rho$ ớócte... ('want julle weet...' 1 Tess 2:1).

Deur bloot te let op White se afbakening van die briefliggaam van 1 Tessalonisense, word die problcem duidelik. Hy laat byvoorbeeld die gedeelte vanaf 3:11 (die derde 'dankseggingsgedeelte') tot 5:11 onbespreek. Dit wil dus voorkom asof die afbakening van die verskillende briefdele in 1 Tessalonisense ' $n$ moeilike saak is, omdat daar onsekerheid bestaan oor die funksie van die briefdeel 'danksegging'.

\subsection{Finale vermanings}

'n Volgende identifiseerbare briefdeel in 1 Tessalonisense is 5:12-27. In hierdie gedeelte kom 'n aantal vorme van vermaning en aanmoediging voor. Daarom word hierdie gedeeltes 'finale vermanings' genoem.

\subsection{Die briefslot}

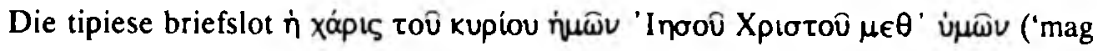
die genade van ons Here Jesus Christus met julle wees'), kom in 1 Tessalonisense 5:28 voor (kyk ook Johanson 1987:65). 
Hiermee is die formele epistolère struktuur van 1 Tessalonisense in breë trekke beskryf. Uit hierdie bespreking blyk dit dat die tradisionele 'dankseggingsgedeelte', as ' $n$ aparte briefdeel, in 1 Tessalonisense moeilik geïdentifiseer en van die brief-liggaam onderskei kan word. Dit blyk verder dat 'danksegging' nie 'n geskikte term is om die briefdele te benoem wat op grond van formele oorwegings as 'danksegging' geidentifiseer kan word nie. Hierdie briefdele voldoen nie aan die vereistes wat aan die taalhandeling 'danksegging' gestel word nie. Teen hierdie agtergrond is dit nodig dat die vraag na die kommunikatiewe funksie van hierdie gedeeltes in 1 Tessalonisense opnuut gevra word. Daarom word die gespreksituasie wat deur hierdie brief veronderstel word, nou ontleed.

\section{3. 'N ONTLEDING VAN DIE GESPREKSITUASIE}

1 Tessalonisense is 'n brief en kenmerkend aan elke brief is die kommunikatiewe funksie daarvan. Wat 'n brief as 'n spesifieke genre identifiseer, is die manier waarop hierdie kommunikatiewe funksie in die teks vervat is (Violi 1985:149). Om hierdie kommunikatiewe funksie van die brief te kan bepaal, word sekere elemente van die gespreksituasie ontleed.

Omdat die fokus van hierdie artikel op die probleem na aanleiding van die 'danksegging(s)' in 1 Tessalonisense gerig is, word die aandag op die deiktiese elemente (verwysings na aspekte van die gespreksituasie) in die 'dankseggingsgedeeltes' (1 Tess 2:2-10; 2:13-16; 3:9-13) gevestig en word die deiksis in die res van die brief nie ontleed nie. Hierdie aspekte word onder andere deur Fillmore (1971) en Violi (1985) bespreek. Die volgende aspekte kan geïdentifiseer word:

* Skrywer (kyk Leech 1983:13; Violi 1985:151-152);

* Leser (kyk Leech 1983:13; Violi 1985:151-152);

* Tyd (kyk Fillmore 1971:28-37; Violi 1985:152-159);

* Ruimte (kyk Fillmore 1971:16-27; Violi 1985:152-159);

* Gedeelde kennis (kyk Leech 1983:13).

3.1 Die identifisering en ontleding van die deiktiese elemente in die 'danksegging' in 1 Tessalonisense

\subsubsection{Die aspek van persoon}

\subsubsection{1 Tessalonisense 1:2-10}

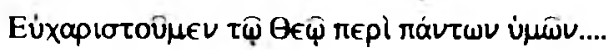




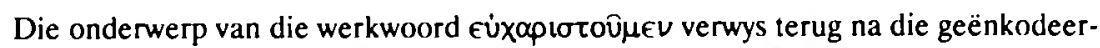

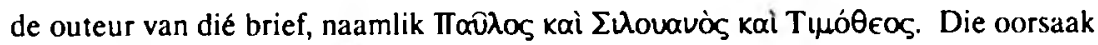
vir die blydskap by die geënkodeerde outeur is 'n derde party en ook die wese aan wie die geënkodeerde outeur sy dank betuig, naamlik $\tau \widehat{\varphi} \Theta \in \bar{\varphi}$. Die party aan wie

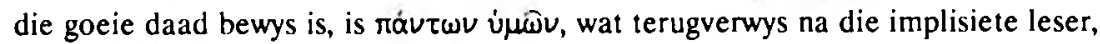

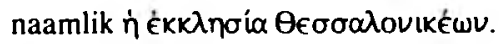

Hoe hou die geënkodeerde outeur homself aan die implisiete leser voor? Die geënkodeerde outeur word hier met die volgende eienskappe vereenselwig:

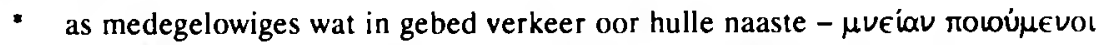

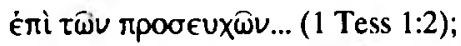

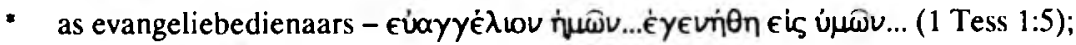

* as yweriges - $\dot{\epsilon} \nu \pi \lambda$ npoфopia... (1 Tess 1:5);

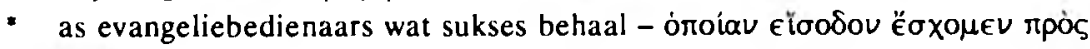
ùuâs... (1 Tess 1:9).

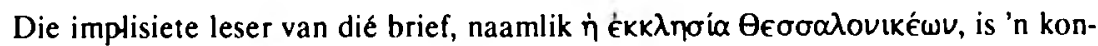
struksie van die geënkodeerde outeur (kyk ook Perelman 1982:19-23), alhoewel aangeneem kan word dat die geënkodeerde outeur sy persepsie so sou probeer vorm dat dit so na as moontlik aan die 'werklikheid' van die situasie sal wees. Omdat die werklike situasie nie vasgestel kan word nie, is dit onmoontlik om te kan sê hoe na die outeur se persepsie van sy leser aan die werklike situasie was. Dit is egter moontlik om op grond van die tekstuele gegewens 'n konstruksie te maak van die geënkodeerde outeur se persepsie van die leser. In hierdie gedeelte in 1 Tessalonisense vermeld die geënkodeerde outeur 'n aantal eienskappe wat hy aan die implisiete leser toeken en wat ook die rede is waarom hy die dank aan die derde party bring. Hier word die implisiete leser voorgestel as

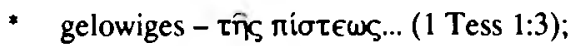

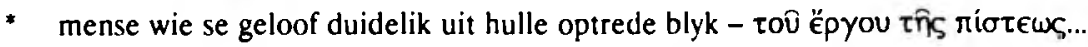
(1 Tess 1:3);

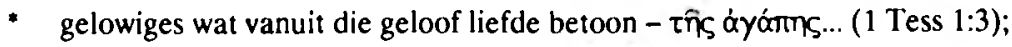

- gelowiges wat hoop op Jesus Christus - tñs é $\lambda$ rífos... (1 Tess 1:3);

* mense wat die evangelie volkome aangeneem het en erns maak met hulle geloof - (1 Tess 1:3);

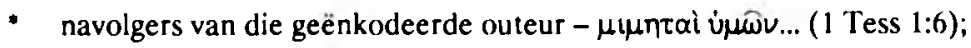

- gelowiges wat die evangelie in verdrukking ontvang het, maar met blydskap -

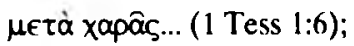

- mense wat voorbeelde is vir ander gelowiges - tútou... (1 Tess 1:7);

- mense wie se geloof vanself spreek (1 Tess 1:8). 
Die gemeentes van Masedonië en Agaje (wat nie 'n volgende party in die 'danksegging' is nie, maar 'n verdere tema is wat daarin bespreek word) word vermeld as gemeentes wat die implisiete leser se geloofslewe bewonder, wil navolg en besing (1 Tess 1:7-10). Hierdie tipering van die gemeentes in Masedonië en Agaje dra ook by tot die tipering van die implisiete leser (kyk 1 Tess 1:7-10).

Die derde party wat dank van die geënkodeerde outeur ontvang, naamlik ó Өeós, word hier soos volg getipeer:

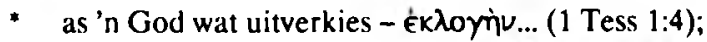

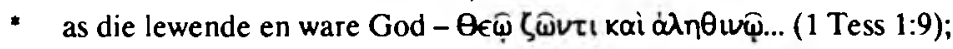

* as die Vader van Jesus wat uit die dood opgewek is en ons so gered het van die wraak wat aan die kom is - tòv vióv... (1 Tess 1:10).

\subsubsection{1 Tessalonisense 2:13-16}

...n்

Soos in die geval van 1 Tessalonisense 1:2-10, verwys ǹueî na die geënkodeerde outeur, naamlik Paulus, Silas en Timoteus. Die ontvanger van die dank en die oorsaak van die dank is weer eens $\tau \hat{\varphi} \hat{\theta} \theta \hat{\varphi}$. Die rede waarom God gedank word, word ingelei met $\not ̈ \tau \iota$, terwyl die implisiete leser die party is wat die goeie daad ervaar het.

In hierdie gedeelte word die geënkodeerde outeur soos volg aan die implisiete leser voorgestel:

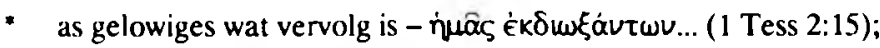

- as evangeliebedienaars wat deur stamgenote verhinder is om tot die heidene te

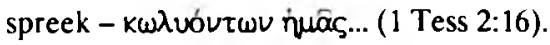

Die implisiete leser word voorgestel as:

- mense wat die Woord van God aanvaar het as komende van God en nie van mense nie - $\lambda$ óyov Oeoû... (1 Tess 2:13);

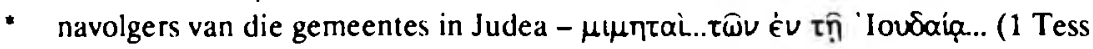
2:14);

- mense wat onder hulle stamgenote gely het (1 Tess 2:14-15).

In aansluiting by die karakterisering van die implisiete leser, dra die beskrywing van die gemeentes in Judea en dié van die stamgenote by om 'n voortreflike voorstelling van die implisiete leser te skep. Tog maak hierdie stamgenote en die gemeentes in Judea nie deel uit van die implisiete leser nie. Hierdie groepe is bloot van die temas wat in die 'dankseggingsgedeeltes' aan die orde kom (kyk 1 Tess 2:14-16). 


\subsubsection{1 Tessalonisense 3:9-13}

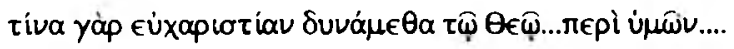

Die onderwerp van die werkwoord $\delta v v \alpha \dot{\alpha} \mu € \alpha$ verwys weer na die geënkodeerde outeur, naamlik Paulus, Silas en Timoteus. Die party wat bedank word, is ó Өeós wat ook die party is wat die goeie daad verrig aan die tweede party, naamlik ujkfic.

'Yueis het betrekking op die implisiete leser, naamlik die Tessalonisense.

Die geënkodeerde outeur word gekarakteriseer as

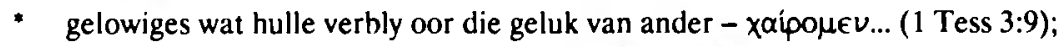

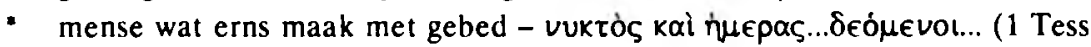
3:10);

- bedienaars van die Woord wat hulle beywer om nasorg te doen met betrekking

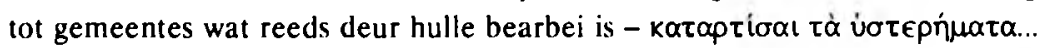
(1 Tess 3:10);

- gelowiges wat oorvloedige liefde teenoor die implisiete leser openbaar - $\dot{\alpha}$ yórṭn

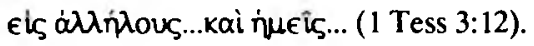

Die volgende eienskap van die implisiete leser word in hierdie gedeelte vermeld:

- die implisiete leser is mense wie se lewens só is, dat die geënkodeerde outeur

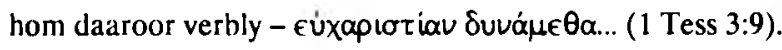

'O Өeós, die derde party, word soos volg gekarakteriseer:

- God is 'n God wat Hom oor sy volgelinge ontferm en Hy sorg vir al hulle behoeftes (1 Tess 3:9-13);

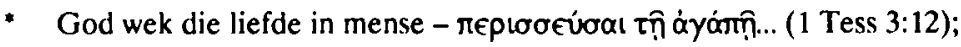

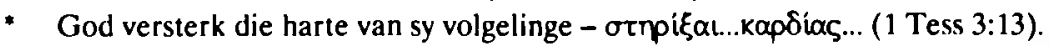

\subsubsection{Samevattend}

Die geënkodeerde outeur word dus gekarakteriseer as: besorg, gelowig, vervolg, liefdevol, evangeliebedienend en ywerig.

Die implisiete leser word voorgestel as: gelowiges in alle opsigte, navolgers van die 'voorbeeldige' geënkodeerde outeur, vervolgdes, voorbeeldiges, liefdevol, mense waaroor die geënkodeende outeur hom verbly en mense waarvoor die geënkodeerde outeur God dank. Die beeld wat van die implisiete leser geskets word, is dus absoluut positief.

Dit is moontlik dat sodanige persoonsdeiksis ook in die ander dele van die brief voorkom en die implisiete leser verder prys, maar vir die doel van hierdie studie word nie daarop ingegaan nie. 


\subsubsection{Die aspek van tyd}

\subsubsection{1 Tessalonisense 1:2-10}

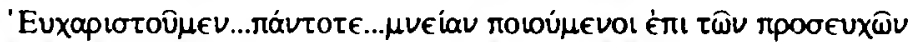

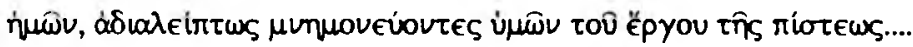
('Ons dank...altyd...wanneer ons in ons gebede onthou, terwyl ons onophoudelik die werk van julle geloof onthou....')

Omdat daar in die teks geen aanduiding is van die spesifieke tydstip waarop die brief geskryf is nie, is dit nie moontlik om die koderingstyd (die tyd waarbinne die brief geskryf is) te bepaal nie, behalwe as daar histories te werk gegaan word. 'n Histories-kritiese analise van 1 Tessalonisense val egter buite die fokus van hierdie studie.

Dit is egter wel moontlik om die referensiële tyd (die tyd waarna daar in die brief verwys word) te bepaal. Wanneer die geënkodeerde outeur meld dat hy God vir al die goeie eienskappe van die implisiete leser dank, sê hy ook dat hierdie dank voortdurend uitgespreek word. Dit is ook moontlik om presies te sê by watter geleenthede hierdie handeling gewoonlik plaasvind. Die geënkodeerde outeur sê dat hy dit doen 'wanneer hy aan die implisiete leser dink in sy gebede' (1 Tess 1:2-3). Hierdie voortdurendheid van die handeling word beklemtoon wanneer die geënkodeerde outeur vermeld dat dit $\alpha \delta \omega \lambda \epsilon i \pi \tau \omega \zeta$ ('ononderbroke') plaasvind.

\subsubsection{1 Tessalonisense 2:13-16}

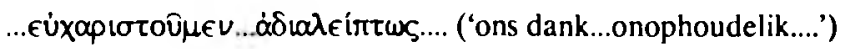

Wanneer hierdie 'dankseggingsgedeelte' vergelyk word met dié in 1 Tessalonisense 1:2-10, lyk dit asof die bywoord $\alpha \delta \omega \lambda \in i \pi \tau \omega c$ 'n nie-kalendriese (d w s, nie presies afgebakende) tyd is binne die versweë kalendriese (presies afgebakende) tyd wanneer ons hid. Reeds in die eerste 'dankseggingsgedeelte' (1 Tess 1:2-10) het die geënkodeerde outeur vermeld dat hierdie 'danksegging' ' $n$ handeling is wat op God gerig is en daarom in gebed plaasvind.

\subsubsection{1 Tessalonisense 3:9-13}

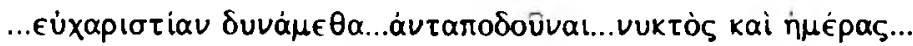

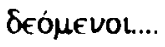

('...kan ons dank...betuig...nag en dag...wanneer ons smeek....) 
Die geënkodeerde outeur maak melding daarvan dat hy voortdurend bid dat God hom die geleentheid moet gee om die implisiete leser te sien. In die loop van hierdie gebed betuig die geënkodeerde outeur dank aan God vir die implisiete leser. Die referensiële tyd is dus ook in hierdie geval 'n vorm van nie-kalendriese tyd (vuktòs kaì njuépas) binne 'n vorm van kalendriese tyd (die gebed).

In die drie 'dankseggingsgedeeltes' word geen melding gemaak van die koderingstyd ('n verwysing na die tyd waartydens die brief geskryf en gelees is) nie. Wat wel in hierdie gedeeltes ' $n$ rol speel, is die herhaalde gebruik van die nie-kalendriese

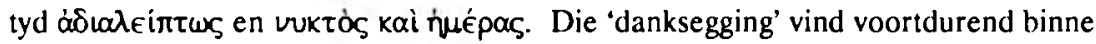
gebed plaas, dag en nag. Die hele handeling van 'danksegging' word dus as ' $n$ onophoudelike handeling voorgehou.

\subsubsection{Die aspek van ruimte}

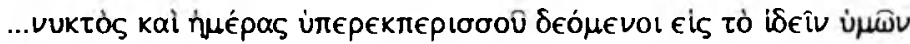

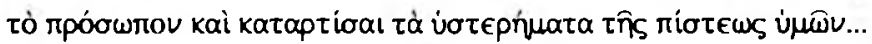
('...wanneer ons nag en dag ernstig bid om julle te sien en om te voltooi wat aan julle geloof ontbreek....')

Uit die derde 'dankseggingsgedeelte' (1 Tess 3:13-16) blyk dit dat die geënkodeerde

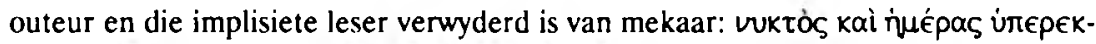

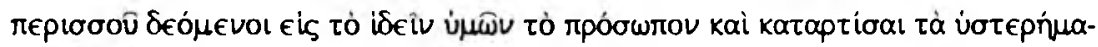

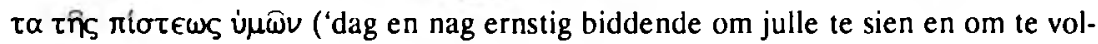
tooi wat aan julle geloof ontbreek') (1 Tess 3:10). Die geënkodeerde outeur meld dat hy voortdurend begeer om die implisiete leser weer te sien en sy werk onder hulle voort te sit. Die presiese lokaliteit van elk is egter nie hieruit te bepaal nie.

Vir die doel van die 'danksegging' het die geënkodeerde outeur dit skynbaar nie nodig geag om die ruimte enigsins te spesifiseer nie (behalwe die feit van verwydering en begeerde hereniging).

\subsubsection{Die aspek van gedeelde kennis}

Leech (1983:13) beskou 'konteks' as enige agtergrondskennis wat gedeel word deur beide die geënkodeerde outeur en implisiete leser. Hierdie gedeelde kennis dra by tot die implisiete leser se interpretasie van die geënkodeerde outeur se uiting.

Gedeelde kennis speel 'n baie belangrike rol in die 'danksegging(s)' in 1 Tessa-

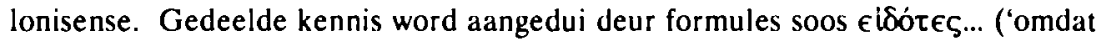

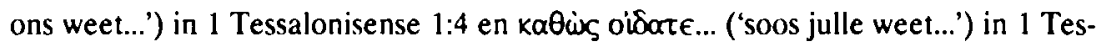


salonisense 1:5. Die geënkodeerde outeur dank God telkemale vir dinge waarvan sowel die geënkodeerde outeur as die implisiete leser bewus is.

Die inhoud van hierdie gedeelde kennis hehels die volgende:

* Sowel die geënkodeerde outeur as die implisiete leser is bewus van die werk van die geënkodeerde outeur onder die implisiete leser.

* Beide partye is bewus van hoe goed die evangelie deur die implisiete leser ontvang is.

* Beide partye weet dat God die implisiete leser genadig is.

* Beide partye deel die kennis oor die goeie hoedanighede van die geënkodeerde outeur en die implisiete leser.

\subsubsection{Sintese}

Uit die ontleding van die gespreksituasie is dit duidelik watter eienskappe aan die verskillende persone toegeken is, hoeveel inligting oor die tyd en ruimte verskaf is en watter en hoeveel gedeelde kennis in hierdie gedeeltes 'n rol speel. Hierdie analise van die 'gespreksituasie' is nuttig vir die toepassing van die beginsel van Grice (1975) op die deiktiese elemente.

\section{DIE TOEPASSING VAN DIE KOÖPERATIEWE BEGINSEL VAN GRICE OP DIE DEIKTIESE ELEMENTE IN DIE 'DANKSEGGING(S)' IN 1 TESSALONISENSE}

Grice (1975:45-46) werk met beide semantiek en pragmatiek wanneer hy die koöperatiewe beginsel hanteer. Hiervolgens is daar vier kriteria waarmee die gespreksimplikasie bepaal kan word, wat weer kan help om die funksie van taaluitinge te bepaal. Hierdie vier kriteria is kwantiteit, kwaliteit, relasie en wyse. Die toepassing van hierdie beginsel is dus ' $n$ stap in die bepaling van die kommunikatiewe funksie.

\subsection{Die toepassing van die beginsel van Grice op die aspek van persone}

Die vraag kan gevra word in watter mate die geënkodeerde outeur by die aspek van persoon ten opsigte van die bogenoemde vier kriteria afgewyk het?

\subsubsection{Kwantiteit}

Die vraag na kwantiteit is of die outeur die verlangde hoeveelheid inligting verstrek het. 


\subsubsection{Die geënkodeerde outeur}

Uit paragraaf 3.1 .1 blyk dit dat daar in die eerste 'dankseggingsgedeelte' nie minder nie as vier goeie eienskappe aan die geënkodeerde outeur toegeskryf word. Die feit dat die hoeveelheid inligting wat die geënkodeerde outeur oor homself verstrek, meer as voldoende is, laat ' $n$ mens dadelik wonder waarom ' $n$ 'goeie beeld' van homself vir die geënkodeerde outeur so belangrik is. Hier is beslis heelwat gegewens verstrek wat op die oog af oorbodig voorkom. Of dit inderdaad oorbodig is, sal later aan die orde gestel word.

In die tweede 'dankseggingsgedeelte' word twee eienskappe van die geënkodeerde outeur vermeld, naamlik dat hulle vervolgdes is en mense wat verhinder word om hulle werk onder die heidene te doen. Wat hierdie inligting merkwaardig maak, is dat hierdie twee eienskappe presies ooreenstem met die inligting wat oor die implisiete leser en die gemeentes in Judea verstrek word. In elke geval is dit die outeur en die gemeentes in Judea wat vergelyk word met dié in Tessalonika. Dit is weer eens 'n geval waar die goeie eienskappe van die implisiete leser beklemtoon word deur dieselfde optrede van ander partye te vermeld en aan te prys. Deurdat die geënkodeerde outeur homself en die implisiete leser met dieselfde eienskappe karakteriseer, identifiseer hy hom met die implisiete leser. Die kriterium van kwantiteit word dus weer eens oortree. Sonder om al hierdie inligting te verstrek, sou die outeur op die oog af slegs kon sê dat die implisiete leser goeie mense is.

In die derde 'dankseggingsgedeelte' word vier eienskappe van die geënkodeerde outeur (kyk \$ 3.1.1) vermeld. Al vier eienskappe hou verband met die verhouding tussen die implisiete leser en geënkodeerde outeur. Dit raak die liefde, sorg, bearbeiding, geluk en gebed van die geënkodeerde outeur met betrekking tot die implisiete leser. Dit wil voorkom of die kriterium van kwantiteit ook hier oortree word.

\subsubsection{Die implisiete leser}

In die eerste dankseggingsgedeelte vermeld die geënkodeerde outeur van hierdie brief nege voortreflike eienskappe van die implisiete leser (bo en behalwe die by-

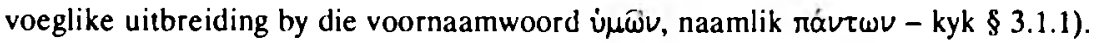
Buiten die verdere voortreflike eienskappe wat in die ander 'dankseggingsgedeeltes' aan hulle toegeskryf word, verteenwoordig hierdie gegewens op sigself al 'n magdom inligting. Daar word uitsluitlik op positiewe eienskappe gekonsentreer. Dit is baie opvallend dat een van hierdie eienskappe, naamlik 'gelowiges wat die evangelie in verdrukking ontvang het, maar dit met blydskap gedoen het' (1 Tess 1:6), ooreenstem met dieselfde eienskap wat ook in die brief aan die geënkodeerde outeur toegeskryf word. Hierby voeg die outeur ook die feit dat die implisiete leser 'navolgers 
is van die geënkodeerde outeur' (1 Tess 1:6). Die vraag is of dit nodig is om die ooreenstemmende eienskappe uit te spel, of kon dit bloot versweë gebly het.

In die derde 'dankseggingsgedeelte' word daar vir die eerste keer in die 'dankseggingsgedeelte' slegs gemeld dat die lewenswyse van die implisiete leser sodanig is dat die geënkodeerde outeur hom daaroor verheug. In hierdie geval is die inligting ten opsigte van kwantiteit voldoende. Die vraag sou egter gevra kan word waarom net die nodigste inligting in hierdie geval verstrek word.

\subsubsection{Die stamgenote en gemeentes in Judea}

In die gevalle waar die gemeentes in Judea en die stamgenote vermeld word, word die hoeveelheid inligting in verband met die implisiete leser verder uitgebrei. Omdat die geënkodeerde outeur klaarblyklik positief is oor die gemeentes in Judea, word daar moontlik geïmpliseer dat die implisiete leser beter oor hulleself behoort te voel. Die karakterisering van die stamgenote is dus weer eens 'n oortreding met betrekking tot die hoeveelheid inligting oor die implisiete leser.

\subsubsection{Die derde pany}

Ook waar die derde party, naamlik God beskryf word, word verdere inligting verskaf oor die implisiete leser se goeie karaktereienskappe. Die derde party is die oorsaak van die besondere goeie voorstelling van die implisiete leser. Hierdie party word geteken as God wat die implisiete leser op die hart dra. Die koppeling van die derde party aan die implisiete leser is die belangrikste rede vir die 'danksegging'. Die feit dat die derde party die implisiete leser op die hart dra, gee die geënkodeerde outeur genoeg rede om dankbaar te voel oor die goeie omstandighede waaronder die implisiete leser verkeer.

Ten opsigte van die kriterium van kwantiteit kom daar dus in die geval van byna al die deiktiese aspekte van persoon een of ander vorm van oortreding voor. In paragrawe 5 en 6 word die implikasies hiervan ontleed.

\subsubsection{Kwaliteit}

Die kwaliteit van inligting word bepaal deur na te gaan of die gegewens die waarheid is en bewysbaar is. Dit is moeilik om te bepaal of die inligting wat die geënkodeerde outeur in verband met die implisiete leser en homself verstrek, waar is of nie. Dat die implisiete leser in alles voortreflik skyn te wees, mag waar wees, maar wanneer in ag geneem word dat die implisiete leser ook negatiewe eienskappe 
behoort te hê, kom dit voor of die geënkodeerde outeur in hierdie opsig die kriterium van kwaliteit oortree. Tog sê die geënkodeerde outeur glad nie dat die implisiete leser geen slegte eienskappe het nie. Die feit dat hierdie slegte eienskappe verswyg word en die goeie eienskappe oorbeklemtoon word, skep egter die indruk dat die implisiete leser slegs goed is. Die geënkodeerde outeur skep dus die indruk dat die implisiete leser 'volmaak' is. Dit is in 'n geringe mate 'n oortreding van die kriterium van kwaliteit.

\subsubsection{Relasie}

Die relasie van inligting word bepaal deur na te gaan of gegewens relevant is of nie. Die geënkodeerde outeur van hierdie brief aan die Tessalonisense verstrek uiteraard verskeie karaktereienskappe in verband met die verskillende persone (geënkodeerde outeur sowel as implisiete leser). Dit is in hierdie stadium moeilik om te sê of al hierdie gegewens vir die doel van die brief relevant is. Die relevansie van die gegewens oor die verskillende persone sal bespreek word wanneer die kommunikatiewe funksie van die 'danksegging(s)' in 1 Tessalonisense bepaal word (kyk §§ 5,6).

\subsubsection{Wyse}

Wanneer die wyse van die aanbieding van inligting bestudeer word, word nagegaan of die geënkodeerde outeur die inligting ondubbelsinnig weergee, kort en kragtig vermeld en of die inligting georden is.

Die geënkodeerde outeur in 1 Tessalonisense verskaf die inligting in verband met homself en die implisiete leser op 'n duidelike en geordende wyse. Die geënkodeerde outeur vermeld 'n groot aantal goeie eienskappe van homself en veral ook van die implisiete leser. Dit is moontlik dat die geënkodeerde outeur hierdeur enige onduidelikheid of misverstand in hierdie verband wil uitskakel. Alhoewel die gegewens oor die verskillende persone die kriterium van kwantiteit oortree, word die inligting oor die persone duidelik uiteengesit. Daar bestaan dus min of geen moontlikheid dat die implisiete leser die gegewens dubbelsinnig sal verstaan nie.

Sover dit die kriterium van wyse aangaan, kom daar dus geen oortreding met betrekking tot die aspek van persone voor nie. In die lig van die resultate wat deur die toepassing van die beginsel van Grice op die aspek van persone $(\$ 4.1)$ verkry is, kan gekonkludeer word dat die geënkodeerde outeur die kriterium van kwantiteit en in 'n geringer mate ook die kriterium van kwaliteit oortree het. In paragrawe 5 en 6 word hierdie belangrike punt verder bespreek. 
4.2 Die toepassing van die beginsel van Grice op die aspek van tyd

Wat die beginsel van wyse en relasie betref, lyk 'n oortreding met betrekking tot hierdie beginsel op hierdie stadium van die studie onwaarskynlik. Sover dit die hoeveelheid inligting rondom die aspek van tyd betref, hou die geënkodeerde outeur baie getrou aan die kriterium van kwantiteit. In elk van die drie 'dankseggings gedeeltes' kom slegs een verwysing na 'tyd' voor. In die eerste twee 'dankseggings-

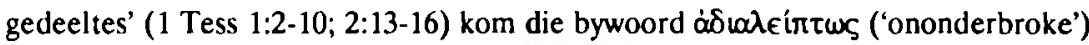
voor, terwyl die genitief van tyd - vuktòs kai nuééas ('nag en dag') - in die derde 'dankseggingsgedeelte' (1 Tess 3:9-13) gebruik word.

Die 'kwaliteit' van die gegewens oor die tyd, met ander woorde of hierdie gegewens 'korrek' is al dan nie, word egter wel in hierdie drie 'dankseggingsgedeeltes' aangeraak. Die geënkodeerde outeur vertel nie doelbewus leuens wanneer hy sê dat hulle 'onophoudelik' hulle dank bring en 'nag en dag' hieroor bid nie. Dit lyk egter na 'n vorm van oordrywing.

4.3 Die toepassing van die beginsel van Grice op die aspek van ruimte Oor die ruimte van die verskillende persone in die 'danksegging(s)' word daar weinig vermeld. Om hierdie rede word 'n verdere toepassing van die beginsel van Grice op hierdie aspek nie voltooi nie. Wat wel duidelik uit die brief blyk, is dat die geënkodeerde outeur en die implisiete leser verwyderd is van mekaar - vandaar die noodsaak vir'n brief.

4.4 Die toepassing van die beginsel van Grice op die aspek van gedeelde kennis Al drie 'dankseggingsgedeeltes' bevat in geheel gedeelde kennis wat die geënkodeerde outeur by die implisiete leser veronderstel. Om die kriterium van kwantiteit op hierdie aspek toe te pas, moet daar versigtig te werk gegaan word. Op die oog af lyk hierdie inligting wat alles gedeelde kennis is, of dit die 'voldoende hoeveelheid' heeltemal oortref. Maar daar sou eers gevra moet word na die funksie van die 'danksegging' voordat besluit kan word of die kriterium van kwantiteit geraak word. Omdat die kommunikatiewe funksie eers in paragrawe 5 en 6 bepaal en omskryf word, word hier slegs op die 'groot hoeveelheid' gedeelde kennis gewys.

Om te kan bepaal of die gedeelde kennis inligting bevat wat histories korrek weergegee is, moet daar noodwendig vanuit 'n histories-kritiese raamwerk hierna gekyk word. Omdat die studie egter nie vanuit 'n historiese raamwerk gedoen word nie, word hierdie gegewens binne die 'dankseggingsgedeeltes' as waarskynlik waar aanvaar. Tog lyk dit of die verswyging van die implisiete leser se negatiewe eien- 
skappe die kriterium van kwaliteit in 'n geringe mate raak. Dit sluit aan by paragraaf 4.1.2. Hierdeur skep die geënkodeerde outeur 'n valse voorstelling van die implisiete leser. Dit beteken dat die kriterium van kwaliteit by die aspek van gedeelde kennis oortree word.

Om aan die kommunikatiewe doel van die 'danksegging(s)' te beantwoord, behoort al die gedeelde kennis oor die implisiete leser en die geênkodeerde outeur relevant te wees. Die teenvraag is egter of die verswyging van die negatiewe eienskappe van die implisiete leser nie juis ook relevant vir die doel van die 'danksegging(s)' is nie? Omdat die doel of die kommunikatiewe funksie van die 'dankseggingsgedeeltes' in 1 Tessalonisense egter nog nie bepaal is nie, word die relevansie van die gegewens en dit wat verswyg is, daargelaat tot in paragraaf 6 .

Omdat die geënkodeerde outeur skynbaar aanvaar dat dit binne die implisiete leser se kompetensie is om sy boodskap te verstaan, word op hierdie punt aanvaar dat die gedeelde kennis nie dubbelsinnig vertolk sal word nie.

\subsection{Gevolgtrekking}

Uit die identifisering en ontleding van die deiktiese elemente binne die drie 'dankseggingsgedeeltes' in 1 Tessalonisense het 'n aantal afwykings of uitbreidings (wat Grice die 'gespreksimplikasie' noem) op die beginsel van Grice na vore gekom. Sover dit die aspek van persone aangaan, het die geënkodeerde outeur 'n mate van verandering ten opsigte van die volgende kriteria van Grice aangebring:

- Kwantiteit: 'n Magdom gegewens oor die persone en in die besonder oor die implisiete leser, word verskaf.

- Kwaliteit: Die geënkodeerde outeur laat die indruk dat die implisiete leser slegs oor goeie eienskappe beskik.

Ten opsigte van die deiktiese aspek van tyd, het die geënkodeerde outeur ten opsigte van die volgende kriterium van die beginsel van Grice afgewyk:

- Kwaliteit: Omdat die bywoorde van tyd ('onophoudelik' en 'nag en dag') 'n oordrywing is, kom die kriterium van kwaliteit in gedrang.

By die aspek van gedeelde kennis wyk die geënkodeerde outeur van die volgende kriteria van die beginsel van Grice af:

* Kwantiteit: Die hoeveelheid inligting wat gedeelde kennis is, word in só 'n mate vermeld dat die drie 'dankseggingsgedeeltes' byna in geheel daaruit bestaan.

* Kwaliteit: Hierdie gedeelde kennis is na alle waarskynlikheid waar; tog lyk dit of die geënkodeerde outeur, met die verswyging van die (beslis aanwesige) negatiewe eienskappe van die implisiete leser, die kriterium van kwaliteit aantas. 
Dit lyk dus of daar oor die algemeen afgewyk is van die kriterium van kwantiteit en in 'n geringe mate ook dié van kwaliteit. Die feit dat die geënkodeerde outeur in hierdie gevalle wel effens afgewyk of uitgebrei het op die beginsel van Grice, is egter nie toevallig nie, maar is juis 'n hulpmiddel om die funksie of doel van die 'danksegging(s)' te bepaal.

Omdat die geënkodeerde outeur sy argument (soos alle retorici) moes beplan met inagneming van die take van die redenaar, word daar gekyk na die eerste taak van die redenaar, naamlik inventio (die vind van die argument). Deur vas te stel hoe die redenaar sy argument gevind het, is dit moontlik om te bepaal waarom hy (bewustelik of onbewustelik) sou verkies om in sekere opsigte van die koöperatiewe beginsel af te wyk. Daarom volg hier nou 'n ontleding van die retoriese situasie.

\section{5. 'N ONTLEDING VAN DIE RETORIESE SITUASIE VAN 1 TESSALONI- SENSE}

\subsection{Inleiding}

Aangesien die doel van hierdie artikel die beskrywing van die kommunikatiewe funksie(s) van die 'dankseggings' in 1 Tessalonisense is, kan 'n formeel-kritiese benadering tot die retoriese situasie nie tot sodanige beskrywing lei nie. Wat die disposisionele en genre-benadering betref, sè Vorster (1991:24) dat 'n retoriese analise nie kan eindig by 'n analise van die dispositio van die teks en die bepaling van genre bloot op grond van die dispositio nie. Ook Lambrecht (1990:199) wys op die gevaar van oordrewe 'genre hunting'. Kraftchick (1990:56) meen dat die identifisering van retoriese genres en vorme dikwels veroorsaak dat die brief binne die retoriese genres ingepas word, terwyl belangrike dele van die teks geignoreer word. Kraftchick (1990:67) is van mening dat klassieke retoriek wel van hulp kan wees by die analise van Paulus se briewe, maar dan nie deur bloot die antieke kategorieë te identifiseer nie, maar deur die argumente, bewyse en stylfigure van die antieke retoriek te ontleed. Alhoewel dit dus ' $n$ belangrike deel vorm van die ontleding van die retoriese situasie, kan daar nie volstaan word met 'n disposisionele en genre benadering van die 'dankseggings' in 1 Tessalonisense nie (soos Wuellner 1990:117-136).

Dit is problematies om die retoriese genres (sonder presiese definiëring daarvan in terme van ander soorte diskoers) sonder meer toe te pas op alle diskoers, aangesien dit die rol van die leser beperk (Vorster 1991:25). Vanweë die problematiek rondom die genre word die genre van 1 Tessalonisense dus nie in hierdie artikel as vertrekpunt geneem nie.

Vir die doel van hierdie artikel word 'retoriese situasie' soos volg verstaan: '[A] complex of persons, events, objects and relations presenting an actual or potential 
exigence which can be completely or partially removed if discourse, introduced into the situation, can so constrain human decision or action as to bring about the significant modification of the exigence' (Bitzer 1968:6).

Binne die retoriese situasie is dit moontlik om vanuit die antieke retoriek die onderliggende probleem waarop die argument toegespits is, naamlik die status van die argument, asook die oorredingsmiddele wat die geënkodeerde outeur gebruik om die probleem op te los, te ondersoek (kyk Leeman \& Braet 1987:66-67, 81-90).

Die vraag na die funksie van die 'danksegging(s)' in 1 Tessalonisense is terselfdertyd ook die vraag na die status van die retoriese situasie. Wanneer dit bekend is watter status die redenaar aan hierdie 'dankseggings' wou toeken, behoort dit moontlik te wees om te verklaar waarom hierdie geënkodeerde outeur byvoorbeeld ten opsigte van die kriterium van kwantiteit afwyk wanneer hy die implisiete leser en homself karakteriseer.

\subsection{Status van die 'dankseggingsgedeelte(s)' in 1 Tessalonisense}

Die status van 'n argument is nie 'n pertinente gegewe in die teks nie en noop die navorser om tussen die lyne van die teks te lees. Om die status van die argument te bepaal, moet die onderliggende probleem waarop die argument toegespits is, geidentifiseer word.

In die eerste 'dankseggingsgedeelte' ( 1 Tess 1:2-10) word die derde party bedank vir die goeie eienskappe waaroor die implisiete leser beskik. Die geënkodeerde outeur is bewus van die implisiete leser se goeie eienskappe deurdat hy vroeër kontak met die implisiete leser gehad het (kyk 1 Tess 1:5, 9). Buiten die opnoem van hierdie goeie eienskappe, laat die geënkodeerde outeur ook blyk dat hy hom met die implisiete leser identifiseer (kyk 1 Tess 1:6).

Ook uit die tweede 'dankseggingsgedeelte' (1 Tess 2:13-16) blyk dit dat die geenkodeerde outeur hom met die implisiete leser identifiseer. In 1 Tessalonisense 2:14-16 gee die geënkodeerde outeur te kenne dat die implisiete leser, soos die geenkodeerde outeur, onder volksgenote moes ly.

In die derde 'dankseggingsgedeelte' (1 Tess 3:9-13) is die aspek van ruimte baie belangrik. Die geënkodeerde outeur het die begeerte om die afstand tussen sy eie ruimte en dié van die implisiete leser te oorbrug (1 Tess 3:10-11). Die feit dat die geënkodeerde outeur van die implisiete leser verwyderd is en graag die afstand tussen hom en die implisiete leser wil oorbrug, noop hom om die brief te skryf.

Waarom sou die geënkodeerde outeur homself met die implisiete leser identifiseer? Waarom word al die goeie hoedanighede van die implisiete leser hier so sterk beklemtoon? Dit wil voorkom of die geënkodeerde outeur deur middel van die 
'dankseggingsgedeeltes' die implisiete leser van sy belangstelling in hulle wil verseker. Die sukses, vooruitgang en geluk van die implisiete leser is ook die geluk van die geënkodeerde outeur. Die vraag kom ook by mens op waarom dit vir die geënkodeerde outeur so belangrik is om die implisiete leser van sy belangstelling te verseker en waarom dit verder belangrik is om sy eie goeie eienskappe uit te lig.

Die status van die 'dankseggingsgedeeltes' in 1 Tessalonisense word beskou as die probleem of die saak waaroor die taaluiting handel. Die onderliggende probleem van die geënkodeerde outeur in hierdie gedeeltes (d w s die status van die probleem) kan soos volg in vraagvorm geformuleer word:

- Hoe kan die implisiete leser oorreed word om nie alleen al hulle goeie hoedanighede te handhaaf nie, maar om ook daarop te verbeter?

- Wanneer sal die implisiete leser hulle leraar (in hierdie geval die geënkodeerde outeur) genoeg vertrou om sy vermanings ter harte te neem?

Bogenoemde vrae, wat moontlik die status van die argument in die 'dankseggingsgedeeltes' in 1 Tessalonisense saamvat, kan op die volgende tekstuele gegewens gegrond word: In die derde 'dankseggingsgedeelte' (1 Tess 3:9-13) lê 'n aantal gegewens opgesluit wat daarop dui dat die geënkodeerde outeur begeer dat die implisiete leser hulle goeie hoedanighede sal behou en daarop voortbou. In 1 Tessalonisense 3:10 kom die geënkodeerde outeur se begeerte om die geloof van die implisie-

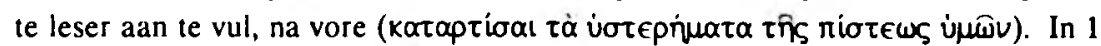
Tessalonisense 3:13 gee die geënkodeerde outeur te kenne dat hy begeer dat die im-

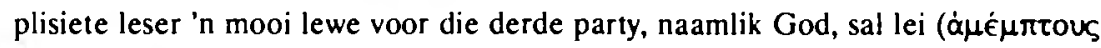
év àywoúun).

In terme van 'n antieke retoriese denkmilieu kan geredeneer word dat die geënkodeerde outeur die volgende redenasie aan die dag kon lê:

- 'n Leser is oop vir oortuiging wanneer hy sy outeur vertrou.

* 'n Leser sal sy outeur vertrou wanneer hy oortuig is dat die outeur 'n goeie mens is en veral 'n goeie mens soos die leser self.

* 'n Leser sal noodwendig sy goeie hoedanighede probeer verbeter indien sy huidige hoedanighede as voortreflike eienskappe bestempel word.

- 'n Leser is oop vir verdere oorreding wanneer sy goeie gesindheid verkry is.

- Wanneer 'n leser se goeie gesindheid verkry is, is dit moontlik om hom selfs vir vermanings ontvanklik te maak.

- Wanneer die leser daarvan oortuig is dat die outeur sy belange op die hart dra. is so 'n leser ontvanklik vir enige verdere oorreding.

Op grond van die status van die argument, kan nou bepaal word watter oorredingsmiddele die geënkodeerde outeur gebruik het om sy probleem op te los. 
5.3 Die oorredingsmiddele gebruik ter ondersteuning van die argument

Die verskillende oorredingsmiddele wat in die antieke retoriek aangewend is (kyk Aristoteles, Ars Rhetorica 1.1), sluit onder meer die volgende in: ethos, pathos en logos.

Die oortuigingsmiddel pathos dien die doel om die karakter van die implisiete leser sodanig te prys dat die implisiete leser 'n goeie gesindheid teenoor die geënkodeerde outeur openbaar en sodoende ontvanklik is vir verdere oorreding. Die oortuigingsmiddel ethos dien die doel om die outeur by die implisiete leser as betroubaar en goed voor te stel.

Te oordeel aan die status wat die geënkodeerde outeur in 1 Tessalonisense aan die 'danksegging(s)' toeken (kyk \$ 5.2), blyk dit dat sowel ethos as pathos die geskikte oortuigingsmiddele was om in hierdie retoriese situasie te gebruik

In al drie 'dankseggingsgedeeltes' is die gebruik van ethos duidelik te bespeur (kyk ook Lyons 1985:177-201). Oor die drie 'dankseggingsgedeeltes' heen word altesaam tien positiewe en prysenswaardige eienskappe aan die geënkodeerde outeur toegeskryf (kyk § 3.1.1). Deur middel hiervan dra die geënkodeerde outeur die volgende boodskap aan die implisiete leser oor: Kyk hoe 'n goeie mens is ek; julle kan my maar vertrou en gehoorsaam; ek gee om vir julle welsyn.

Wanneer die oortuigingsmiddel pathos gebruik word, word die emosies van die implisiete leser betrek om hulle sodoende vir die argument gunstig te stem (Aristoteles, Ars Rhetorica 1.2.2). Aristoteles (Ars Rhetorica 3.7.3) verduidelik dat dit belangrik is om op die emosies van die hoorder (leser) aanspraak te maak. Dit kan onder andere bereik word deur goeie eienskappe aan te prys (Ars Rhetorica 3.7.3).

Dit is moontlik om op grond van hierdie inligting die afleiding te maak dat die oortuigingsmiddel pathos taaluitinge soos volg beïnvloed:

* die slegte eienskappe van die implisiete leser word taktvol verswyg;

* slegs die goeie hoedanighede word vermeld;

- die goeie hoedanighede word in 'n oordrewe mate deur die geënkodeerde outeur aangeprys.

Pathos, as oorredingsmiddel, is in die drie 'dankseggingsgedeeltes' in 1 Tessalonisense in 'n groter mate as ethos deur die geënkodeerde outeur gebruik. Die geënkodeerde outeur ken dertien goeie eienskappe aan die implisiete leser toe en verswyg konsekwent die slegte eienskappe (kyk \$3.1.1). Deur die vermelding van dertien goeie eienskappe van die implisiete leser asook deur die wyse waarop dit vermeld word, speel die geënkodeerde outeur as 't ware met die emosies van die implisiete leser. 'n Geënkodeerde outeur wat soveel lof vir sy implisiete leser het, sal 'n nog positiewer reaksie op enige verdere bevele of versoeke kry - en dit omdat die implisiete leser emosioneel positief hierdeur beinvloed is. In 1 Tessalonisense 2: 14 - 
15 word die implisiete leser weer eens emosioneel beïnvloed wanneer die geënkodeerde outeur die verskriklike lyding van die implisiete leser in herinnering roep. Hy vermeld verder in 1 Tessalonisense 2:16 dat ook hy as geënkodeerde outeur soortgelyke lyding moes verduur.

Dit is dus duidelik dat beide die oortuigingsmiddele ethos en pathos in hierdie gedeeltes in 1 Tessalonisense aangewend is.

5.4 Die plek van die oortuigingsmiddele 'pathos' en 'ethos' in 'n toespraak of brief Omdat die oortuigingsmiddele pathos en ethos ten doel het om die implisiete leser se goeie gesindheid te verkry, word hierdie oortuigingsmiddele veral in die opening van 'n brief of toespraak aangewend. Dit is belangrik om die implisiete leser, reeds voor die aanvang van die briefliggaam, ontvanklik te maak vir die briefliggaam en hulle gunstig te stem teenoor die geënkodeerde outeur (Leeman \& Braet 1987:5996). Dit is egter nie net moontlik nie, maar ook noodsaaklik om hierdie oortuigingsmiddele in die loop van die toespraak of brief te gebruik (kyk Ars Rhetorica 3.14.9).

In paragraaf 2.2 is White se analise van die briefliggaam van 1 Tessalonisense weergegee. Daarvolgens open 1 Tessalonisense 2:1 die briefliggaam (vanweë die

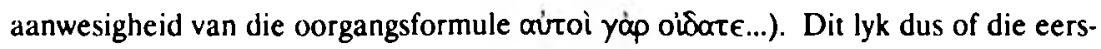
te 'dankseggingsgedeelte' (1 Tess 1:2-10) deel vorm van die briefopening, terwyl die oorblywende twee 'dankseggingsgedeeltes' (1 Tess 2:13-16; 3:9-13) deel uitmaak van die briefliggaam. Die veelvuldige en willekeurige gebruik van die oortuigingsmiddele ethos en pathos is egter geregverdig. Dit staan die geënkodeerde outeur vry om hierdie twee oortuigingsmiddele aan te wend wanneer dit hom pas.

Omdat dit belangrik is om die implisiete leser se goeie gesindheid voor die aanbieding van die briefliggaam te verkry, is dit logies dat ethos en pathos oorvloediger gebruik sal word in die briefopening. Daarom word ethos en veral pathos baie uitgebreid in die briefopening aangewend (kyk 1 Tess 1:2-10) en veel minder in die briefliggaam self (kyk 1 Tess $2: 13-16 ; 3: 9-13)$. Dit is dus nie nodig om die voorkoms van meerdere 'danksegging(s)' in die briefliggaam as 'n probleem te beskou nie.

\section{GEVOLGTREKKING}

Daar is op grond van 'n ontleding van die aard van die taalhandeling 'danksegging' aangetoon dat die drie gedeeltes in 1 Tessalonisense wat tradisioneel as 'danksegging(s)' geidentifiseer word, in der waarheid nie die funksie van 'danksegging' in hierdie brief vervul nie. 
Alhoewel hierdie drie 'dankseggingsgedeeltes' ' $n$ taalhandeling is waarin die geenkodeerde outeur sy dank uitspreek, is die bedoeling nie 'n danksegging nie. Die resultate van hierdie ondersoek kan soos volg saamgevat word:

* Die term 'danksegging' is nie geskik om 1 Tessalonisense 1:2-10, 2:13-16 en 3:913 te karakteriseer nie.

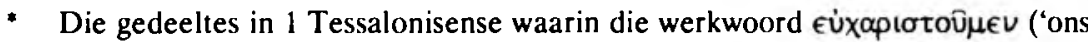
dank') voorkom, dien eerder die doel van pathos en ethos.

* Deur die gebruik van ethos skets die geënkodeerde outeur 'n navolgingswaardige beeld van homself om sodoende die implisiete leser se vertroue in hom te verseker.

* Deur die gebruik van pathos verkry die geënkodeerde outeur sy implisiete leser se goeie gesindheid.

* Deurdat die implisiete leser se goeie gesindheid verkry word, word die implisiete leser ontvanklik gemaak vir verdere oorreding.

Die gedeeltes in 1 Tessalonisense, bekend as 'dankseggings', kan dus eerder beskou word as voorbeelde van pathos en/of ethos.

\section{Literatuurverwysings}

Aland, K, Black, M, Martini, C M, Metzger, B M \& Wikgren, A (eds) 1983. The Greek New Testament. 3rd ed (corrected). Stuttgart: UBS.

Aristoteles, H L 1947. Ars Rhetorica. London: William Heinemann. (Loeb Classical Library.)

Bitzer, L F 1968. The rhetorical situation. Philosophy and Rhetoric 1, 1-24.

Boers, H 1975/76. The form critical study of Paul's letters: 1 Thessalonians as a case study. NTS 22, 140-158.

Bolkestein, M H 1974. De prediking van het Nieuwe Testament: De brieven aan de Tessalonicenzen. Nijkerk: Callenbach.

Botha, J 1989. On the 'reinvention' of rhetoric. Scriptura 31, 14-31.

Collins, R F 1979. A propos the integrity of 1 Thessalonians. EThL 55, 67-106.

Doty, W G 1973. Letters in primitive Christianity. Philadelphia: Fortress.

Fillmore, C T 1971. Santa Cruz lectures on deixis. Indiana: Indiana Linguistics Club. Finday, G G (ed) 1914. The epistle to the Thessalonians. Cambridge: Cambridge University Press.

Frame, J E 1946. A critical and exegetical commentary on the epistels of St. Paul to the Thessalonians. Edenburgh: T \& T Clark. 
Grayston, K 1967. The letters of Paul to the Philippians and to the Thessalonians: The Cambridge Bible commentary on the New English Bible. Cambridge: Cambridge University Press.

Grice, H P 1975. Logic and conversation, in Coe, P \& Morgan, T L (eds), Syntax and semantics 3,41-271. Santa Cruz: University of California.

Johanson, B C 1987. To all the brethren: A text-linguistic and rhetorical approach to 1 Thessalonians. Stockholm: Almquist \& Wiksell International.

Koskenniemi, H 1956. Studien zur Idee und Pharaseologie des Griechieschen Briefes bis $400 \mathrm{nChr}$. Helsinki: Akateemin Kirjakauppa.

Kümmel, W G 1975. Introduction to the New Testament. London: SCM Press.

Lambrecht, J 1990. Thanksgivings in 1 Thessalonians 1-3, in Collins, R E (ed), The Thessalonian correspondence, 183-205. Leuven: Peeters.

Leech, G N 1983. Principles of pragmatics. London: Longman.

Meyer, H A W (ed) 1880. Critical and exegetical commentary on the New Testament. Edinburgh: T\& T Clark.

Morris, L 1959. The first and second epistles of the Thessalonians: The English text with introduction, exposition and notes. London: Marshall, Morgan and Scott.

-.- 1960. The epistles of Paul to the Thessalonians: An introduction and commentary. London: The Tyndale Press.

O'Brien, P T 1977. Introductory thanksgivings in the letters of Paul. Leiden: Brill.

Quintilianus, M F 1947. Institutio oratoria, vol I-IV. London: Heinemann. (Loeb Classical l. ibrary.)

Schubert, P 1939. Form and function of the Pauline thanksgivings. Berlin: Tope]mann.

Snyman, A H 1989. 'n Retoriese inleiding van die brief aan Filemon. Acta Academica 21/2, 130-144.

Sparks, H F D (ed) 1969. The New Clarendon Bible: Thessalonians. Oxford: Oxford University Press.

Van Aarde, A G 1989. Verslag van die Colloquium Biblicum Lovaniense XXXVIII. HTS 45/1, 166-167, 173-174.

Van Leeuwen, J A C 1926. Kommentaar op het Nieuwe Testament: Paulus'zendbrieven aan Efeze, Colosse, Filemon en Thessalonika. Amsterdam: H A van Bottenburg.

Violi, P 1985. letters, in Van Dijk, T A (ed), Discourse and Literature 3, 149-167. Amsterdam: John Benjamin.

Vorster, J N 1990. Toward an interactional model for the analysis of letters. Neotestamentica 24/1, 107-130. 
Vorster, J N 1991. The rhetorical situation of the letter to the Romans - an interactional approach. DD-proefskrif, Universiteit van Pretoria.

White, J L 1972. The form and function of the body of the Greek letter: $A$ study of the letter-body in the non-literary papyri and in Paul the apostle. Montana: Scholars Press. (Society of Biblical Literature, Dissertation Series, 2.)

--- 1984. New Testament epistolary literature in the framework of ancient epistolography, in Haase, W (ed), Aufstieg und Niedergang der Römischen Welt, Teil 2, Vol 25/2, 1730-1756. Berlyn: De Gruyter.

-- 1986. Light from ancient letters. Philadelphia: Fortress.

Wuellner, $W$ 1990. The argumentative structure of 1 Thessalonians as paradoxical encomium, in Collins, R E (ed), The Thessalonian correspondence, 117-136. Leuven: Peeters. 